\title{
Knowledge on the Environmental Disaster Occurrence in the Democratic Republic of the Congo: The Case of Flooding and Bushfire in Businga Territory, Nord Ubangi
}

\author{
Koto-te-Nyiwa Ngbolua ${ }^{1,2,3^{*}}$, André Nzamonga Gamo ${ }^{2}$, \\ Amédée Kundana Gbatea ${ }^{1}$, Trésor Mbombo Limbaya ${ }^{2}$, \\ Adèle Chimanuka Mwinja ${ }^{4}$, Gédéon Bongo Ngiala ${ }^{1}$, \\ Colette Masengo Ashande ${ }^{1}$ and Ruphin Djoza Djolu ${ }^{1}$ \\ ${ }^{1}$ Department of Environmental Sciences, University of Gbado-Lite, Gbado-Lite, \\ Democratic Republic of the Congo. \\ ${ }^{2}$ Department of Environmental Sciences, University of Nord-Equateur, Gbado-Lite, \\ Democratic Republic of Congo. \\ ${ }^{3}$ Department of Biology, University of Kinshasa, Kinshasa, Democratic Republic of the Congo. \\ ${ }^{4}$ Department of Environmental Sciences, Henan University, Kaifeng, China.
}

Authors' contributions

This work was carried out in collaboration between all authors. Authors KTNN and AKG designed the study, performed the statistical analysis, wrote the protocol and wrote the first draft of the manuscript. Authors ANG, TML and GNB managed the analyses of the study. Authors ACM, GNB, CMA and RDD managed the literature searches. All authors read and approved the final manuscript.

Article Information

DOI: 10.9734/AJGR/2019/v2i130077 Editor(s):

(1) Dr. Xu Chong, Professor, Institute of GeologyChina Earthquake Administration, Beijing, China.

(1) Remember Samu, Middle East Technical University Northern Cyprus Campus, Turkey. (2) Shubham Pathak, Asian Institute of Technology, Thailand. Complete Peer review History: http://www.sdiarticle3.com/review-history/45800

Original Research Article

Received 25 October 2018

Accepted 30 January 2019

Published 01 March 2019

\section{ABSTRACT}

Aims: The aim of this research was to assess the knowledge, perceptions and attitudes of victims and stakeholders on environmental disasters occurring in Businga territory.

Study Design: This research employed a descriptive study design whereby the characteristics of respondents were described. 
Place and Duration of Study: The study was carried out in Bodangabo, Businga and Karawa sectors of Businga territory in Nord-Ubangi, Democratic Republic of the Congo between January 2016 and December 2017.

Methodology: A survey was conducted on 150 respondents among the victims and stakeholders in the prevention and management of environmental disasters in three sectors of Businga territory to whom the semi-structured questionnaire was administered.

Results: The findings show that $54 \%$ of environmental disasters originate from bushfire and $46 \%$ from floods. The bushfire is more evident in the area of Bodangabo and Karawa, while the flood is noticed in the area of Businga precisely in the city, because the $3 / 4$ is largely crossed by streams (Likpolo, Lokame, Legbala, Mongala). Thus, $80 \%$ of disaster victims are not satisfied with the support. However, 96\% of respondents denied the provincial government's contribution, 92\% confirmed the total absence of the environmental disaster prevention policy, and $88 \%$ confirmed the inefficiency of disaster prevention mode in Businga territory. With regard to the period of onset of disasters, it is clear from this survey that the floods are sporadic and occurring every two or three years compared to the bushfire which is manifested every year. $68 \%$ of the difficulties are due to lack of awareness due to insufficient financial resources and $32 \%$ to the shortage of qualified personnel for the prevention and management of these disasters.

Conclusion: The lack of a policy of prevention and management of environmental disasters both at the provincial and local levels is at the base of this high frequency. Therefore, it is relevant that a provincial body responsible for alerting and advocating to the stakeholders involved in the prevention and management of environmental disasters, to settle in all Businga sectors. Furthermore, it is necessary to install the early warning system as tool of disaster prevention.

Keywords: Victims; stakeholders; environmental disaster; Businga, Nord-Ubangi; Democratic Republic of the Congo.

\section{INTRODUCTION}

In accordance with the law of the Democratic Republic of the Congo (DRC), "everyone has the right to a healthy environment conducive to full development and has to defend it." The State shall ensure the protection of the environment and the health of its population [1-2]. In recent years, several Institutions preserving archives have been victims of significant damage as a result of natural or man-made disasters. A few minutes may be sufficient for the memory of a people to be severely damaged or even disappeared [3].

The word disaster is derived from the Medieval French word "désastre" meaning "misfortune", "calamity" and "misadventure" and also it has an Old Italian connection with the word disastro, which refers to mischance and ill luck [4]. While in the ancient Greece and Rome disaster was used more in either astronomical or astrological contexts referring to the destruction or deconstruction of a star as a disaster [4]. According to Srivastava, a "Disaster is a sudden, calamitous event, bringing great damage, loss, destruction and devastation to life and property. The damage caused by disasters is immeasurable and influences the mental, socioeconomic, political, and cultural state of the affected area. Disasters are events that inflict great damage, destruction, and human suffering. Their origin can be natural, such as earthquakes, floods, and hurricanes, or of human origin: Accidents, terrorist acts, deforestation, etc. [5].

On the other side, the United Nations defined a disaster as -the occurrence of sudden or major misfortune which disrupts the basic fabric and normal functioning of the society or community [4]. Sometimes, a disaster also describes a catastrophic situation in which normal patterns of life or ecosystem have been disrupted and extraordinary emergent interventions are required to save and preserve human lives and his environment [4,6-7]. Moreover, disasters can occur due to some factors notably climatic changes, deforestation or unsustainable methods of practices [8]. So, despite achievements in public health, education, women's rights and literacy disasters are having an ever-deeper impact on those least equipped to deal with them - taking away any gains made - as well as impinging on the lives of those who might have felt themselves somehow safe $[6,9]$. It can be distinguished two types of disasters namely: sudden impact disaster or natural disasters such as (floods, earthquakes, tidal waves, cyclones, volcanic irruptions and landslides), and slowonset disaster or man-made disasters (drought, famine, environmental degradation, deforestation, pest infection and desertification). We also 
have the epidemic disaster where microorganisms are spread (cholera, measles, SARS, and HIV) and today Ebola can be added to this list along with many others [5-6]. The environmental catastrophe is defined as an event that endangers one or more ecosystems. Some experts have defined it more scientifically as the result of the impact of a natural or anthropogenic hazard on a socio-economic system with some degree of vulnerability that prevents the affected society or population from coping as it is suitable for this impact [10-11].

Deforestation, mining and the decline of traditional irrigation and agricultural systems have caused land degradation on a large scale, leading to one of the worst drought conditions. In India, the 1987 drought, was one of the worst of the 20th century while in 2001, more than eight states suffered the impact of severe drought [6]. These natural calamities have not only have become a problem for the state but also has become a threat to the sustainable development due to frequent occurrences $[6,12]$.

The severity of these impacts associated with natural disasters is greatly affected by the appropriateness of the built human environment and settlement patterns [13]. A powerful earthquake, for instance, in an unpopulated area is not a disaster, while a weak earthquake which hits an urban area with buildings not constructed to withstand earthquakes, can cause great misery [13]. Any hazard can turn into a disaster when people living in danger zone are vulnerable and are not able to absorb the shock. So a natural disaster can best be understood as a combination of a natural hazard and the vulnerable condition of people [6].

Amongst several natural disasters known, flooding is the leading natural disaster in the world and one of the major environmental challenges faced by many nations in the twentyfirst century [14]. The applied sciences bridge this divide by claiming floods have both natural and anthropogenic causes that result in damages being associated with a natural phenomenon. As the variety of definitions across major scientific disciplines clearly illustrates, flood events are multidimensional [15]. According to the natural sciences, floods occur when streamflow greatly exceeds average values due to unavoidable and natural hydroclimatic phenomena. In contrast, the social sciences define floods as a purely socially constructed event that occurs when water causes damages to human life and property [15].
Floods are complex processes that involve physical and socio-economic factors. Accordingly, flood disasters are the result of both societal and hydro-meteorological factors. It is important to make a distinction between hydrologic and damaging floods [16-17]. The difference is that a hydrologic flood, occurring in an unpopulated area, may cause no damage and therefore, flood disasters are the result of the interaction between hydrologic floods and societal systems. The latter include many subsystems that determine the level of interaction, such as flood mitigation policies and the numbers of people and properties exposed to the risk [17]. Moreover, floods are the most costly and wide reaching of all natural hazards and are responsible for up to 50,000 deaths and adversely affect some 75 million people on average worldwide every year [18].

River floods are considered one of the most important natural disasters in the world and causes huge damages every year, both in economic consequences and fatalities [19]. In the developed countries such as Switzerland, Austria, The Czech Republic, Slovakia, Poland, Hungary, Croatia, Serbia and Germany, extreme floods were characterized by huge losses in damage to economic activity [20]. The focus was on the flooding occurred in parts of Germany in 2013 (overall losses US $\$ 12,500 \mathrm{~m}, 25$ fatalities). Meanwhile in the developing countries, where the flood protection standards are the lowest, coping with floods is even harder and result besides economic damages in many fatalities. Examples of this are the flooding of parts of Nigeria in 2012 (overall losses US\$500m, 363 fatalities) and Pakistan in 2011 (overall losses US\$2,500m, 520 fatalities) [19]. Several studies reported the flooding events in different countries in Europe as described above but mainly in Africa (like Algeria, Benin, Burkina Faso, Cote d'lvoire, DRC, Ethiopia, Gambia, Ghana, Guinea, Kenya, Liberia, Mali, Mauritania, Nigeria, Rwanda, Senegal, Sierra Leone, South Africa, Togo, Uganda, Zambia, Zimbabwe) and Asia (India, Thailand, Cambodia, Vietnam, Laos, The Philippines) as developing continents where the economy is low, this makes the situation very difficult especially when the affected areas are inaccessible. This worsens the situation because it would be very tough to accurately access the death toll $[6,14,18,21-24]$. It should be noted that all communities (rural or urban) is vulnerable to hazards. However, different regions will be more prone to certain types of hazards then others. Natural hazards are those triggered by climatic 
and geographical variability, which is at least partly beyond the control of human activity.

The occurrence of extreme floods is expected to increase even more in the future due to a constantly changing world. Socio-economic factors and climate change are considered the main drivers of the increase in flood risk [19]. Furthermore, floods had several socio-economic and political implications which caused a wide range of complex issues. Some of the immediate consequences included the displacement of people, the destruction of infrastructure such as houses and roads, damage to forms and crops and loss of cattle and livestock. The destruction of roads and other infrastructure delayed ongoing development initiatives and political processes, hence the under development of many African countries [18,26-27]- Ismail, Theron]. It is clear that the increasing population of our planet is leading to the increasing exposure of people and property to hazards of flooding [18].

The occurrence of extreme floods is expected to increase even more in the future due to a constantly changing world considering the rapid increase human population in the last century [28]. The most common causes of floods are climate related, most notably rainfall. Prolonged rainfall events are the most common cause of flooding worldwide. These events are usually associated with several days, weeks or months of continuous rainfall. Human impacts on river catchments influence flood behavior. Land use changes in particular have a direct impact on the magnitude and behavior of floods [18]. However, socio-economic factors like urbanization, increase in wealth, increased demography and economic development have caused that more people and more valuable assets are prone to flooding [28]. On the other side, deforestation results in increased run-off and often a decrease in channel capacity due to increased sedimentation rates [18]. However, flooding has a wide range of health consequences such as drowning, injury, outbreak of gastroenteritis, respiratory infections, poisoning, communicable diseases, epidemic diseases such as cholera, diarrhoea, and dengue fever, poor mental health, and among others [14].

In DRC, DREF under the International Federation of Red Cross and Red Crescent Societies reported recently the flooding disaster that occurred in Gemena in Sud Ubangi province. In 2016, rain and violent winds intensified causing extensive floods in the neighbor hoods located on the banks of rivers Mombonga, Sukia and Labo [29]. The National Society noted the destruction of 105 houses, while173 families lost their household possessions. Four wells out of seven in this town were contaminated with dirty rainwater and 200 household latrines. There is a high risk of a public health disease outbreak due to the proliferation of vector and water-borne diseases [29]. However, heavy rains in Kinshasa seriously affected 1,500 families in 11 high risk municipalities of Kinshasa in 2009. According to weather forecast, the volume of water reached $222 \mathrm{~mm}$ per square meter, a rate never reached since 1961. The force of the water caused serious landslides and erosion in many municipalities communes, killing 31 persons and causing the destruction of or damage to 1,500 homes. About 11,000 people were directly affected by the effects of the disaster in their localities (lack of food, clothes, and other non food items, etc.) [30]. Lately in 2018, Kinshasa faced the same problem of heavy rains which caused flooding with several damages as observed in previous years [31]. Following the disaster occurrence, an evaluation was carried out and helped draw up a plan of action with relief operation, sensitization of the populations on hygiene and sanitation, and building capacities [30]. Despite these and other advancements, the common recurrence of devastating floods around the world indicates there are still many remaining challenges [15]. To assess and carefully handle these risks, studies are needed in order to measure the risk and map them in order to give an overview of the most vulnerable regions. The utmost goal of the United Nations Programme for World Food (WFP) and the United Nations Development Programme (UNDP) is to strengthen the capacity of experts and support these latter who would advise the minister of solidarity and humanitarian actions. Their aim is to support developing countries in the strategy of prevention and management of environmental disasters [32-33].

On the other side, bushfires also constitute a real disaster in regions where deforestation is practiced in an abusive way. Bushfire can be defined as the unplanned vegetation fire. It is a generic term including grass fire, forest fires and scrub fires both with and without a suppression objective. Bushfire mitigation are activities which are undertaken for the purpose of minimizing the incidence and impact of bushfires. The chance of a bushfire occurrence which have harmful consequences to human settlement, economic, environmental and cultural assets is very high 
[34]. Bushfires can be caused either naturally or by the actions of people, either accidentally or deliberately. Although lightning is a common cause of bushfires, most are started by people. During extreme bushfire weather any fire has the potential to be devastating as is the case of Australia [35].

In Ghana for instance, many policy makers expressed the satisfaction with the promulgation of the bushfire way and the consequent establishment of the Nations Bush Fire Committees because it led to a massive reduction in bushfire cases [36]. This, though, was not achieved immediately until after a massive bushfire campaign that drove home the need to protect and conserve nature and its resources [36].

The will of the DRC in the policy of prevention and management of environmental disasters, would be to increase its capacity in anticipating the risks of environmental disasters and to improve its performance in case of the occurrence of environmental hazards. Therefore, different means of collection and processing have been developed by the Government including regular dissemination of data of these hazards as reported by the Disaster Relief Emergency Fund DREF [37-38]. These changes put increasing pressure on governments and other decisionmaking instances for dealing with these extreme events and because extensive flooding is likely to occur in multiple countries at the same time, it puts increasing pressure on trans-national risk reduction [39]. Therefore, DRC plans and coordinates the interventions of all stakeholders working in this field for the reduction before, during and after environmental disasters as DREF [31]. The aim of the present study was to assess the knowledge, perceptions and attitudes of victims and stakeholders on environmental disasters in Businga territory. The significance of this survey was to show the importance of material, economic and human damages caused by environmental disasters in Businga territory. Politically, the once-neglected disaster situation currently occupies a prominent place on the political and social front, to accompany and alert administrators and decision-makers in their disaster-prevention program in this area.

\section{MATERIALS AND METHODS}

\subsection{Study Area}

The present study was carried out between January 2016 and December 2017 in Businga territory located in the north-west of DRC $\left(3^{\circ} 20^{\prime} 19^{\prime \prime}\right.$ North latitude and $20^{\circ} 53^{\prime}$ 09" East longitude, at $400 \mathrm{~m}$ of altitude) [6]. The climate found in Businga territory is of the $\mathrm{AW}_{2}$ type according to the Köppen classification i.e. this territory is subjected to heavy rains during the year [37-38]. The study period was between January 2016 and December 2017.

\subsection{Study Design}

This research employed a descriptive study design whereby the characteristics of respondents were described. The choice of this design was required by the nature of the issue being studied. The community was selected because it has experienced floods for several consecutive rainfall seasons. The researcher had discussions with key informants and stakeholders at the community level i.e. randomly sampled households at sector level.

\subsection{Sample Size and Target Population}

A purposive sampling is entirely based on the judgement of the researcher in that a sample is composed of elements that contain the most characteristics, representative or typical attributes of the population [18]. The questionnaire enabled structured social interaction between the researcher and the respondents thereby providing an opportunity to obtain quantifiable and comparable information related to the study [40]. The semi-structured questionnaires containing open and closed questions enabled the researcher to carry out an objective probe to the sampled population in Businga territory.

In Businga territory, three sectors were selected randomly namely Bodangabo, Businga and Karawa whereby 150 respondents (i.e. 50 respondents per sector). The selected informants were interviewed using an open-ended questionnaire. Socio-demographic characteristics (gender, age, level of education, duties and seniority) were assessed and the evaluation on the knowledge, perception and attitude of victims along with stakeholders involved in the prevention and management of environmental disasters. This last aspect constitute the qualitative part of this research. The interview was held with all the informants (disaster victims ad stakeholders) which comprised all critical players having a role to play in the management of floods and bushfire in Businga territory using a questionnaire where the victims and the stakeholders. 


\subsection{Data Analysis}

All data collected from the questionnaires were coded and transferred to Excel 2010 where findings were presented in a descriptive form through summary measures such as frequency and percentage distribution in a tabular form.

\section{RESULTS AND DISCUSSION}

\subsection{Socio-demographic Characteristics}

The socio-demographic characteristics of the respondents is presented in the Table 1.

The survey was conducted with 150 victims and stakeholders involved aged between 23 and 65 years. Age classes $\geq 63$ years, 58-62 years, 5357 years and $48-52$ years constitute $56 \%$ of victims and stakeholders involved. Age classes 23-27 years, 28-32 years, 38-42 years and 43-47 years are the least represented.

There was a predominance of males than females. This could be justified by the fact that men are used to going early to the bush to set traps to capture the games and came back home while females stayed to arrange the house before going to the farm. As shown above, there is a predominance of married people in the three sectors aforementioned than bachelors, though the high percentage of single is found in Bodangabo. Mwape [18] reported similar findings in his study carried out in Kazungula district, Zambia. The author found a predominance of males over females and married than other groups. In terms of ages, the author found that most of respondents were aged between 30 and 34 years.

Regarding the education level, most of respondents have a secondary level (56\%), followed by $20 \%$ of respondents having a primary level $(20 \%)$, the respondents having a university level $(16 \%)$ while $8 \%$ are illiterate. Seeing this situation, it is obvious that most of respondents have a needed level to comprehend explicitly the questionnaire administered to them. Furthermore, $84 \%$ of respondents are victims of disasters while $16 \%$ are stakeholders in disaster management and prevention. This shows that the number of casualties is greater within Businga territory. Most of the respondents (80\%) live in this area for more than 5 years. This confirms the fact that the respondents possess sufficient knowledge of their environment and of the disasters which occurred in Businga territory. They are able to give reliable information in the field of disaster prevention and management in this area.

Fig. 1 shows the distribution of vulnerable areas to environmental disasters in Businga territory.

It is clear from this figure that all sectors Businga territory present disaster-prone areas. These areas are divided as follows $41 \%$ in the Businga sector in the area of flooding, $33 \%$ in the Karawa sector for the bushfire, $23 \%$ in the Bodangabo sector for the bushfire and $3 \%$ in the city of Businga for the flooding. Thus, the sector Bodangabo and that of Karawa present $56 \%$ of areas which are vulnerable to the bushfire while $44 \%$ of the flood in the area of Businga.

\subsection{Knowledge on the Prevention and Management of Environmental Disasters}

The level of knowledge on different aspects of prevention and management of environmental disasters of the respondents is presented in the Table.

It was observed that $92 \%$ of respondents are aware of environmental disasters while only $8 \%$ are not aware of these disasters i.e. the local population knows the reality happening to them. This high level of knowledge may help so much in the management of these disasters.

In regards to the level of satisfaction on the environmental disaster support, it is observed that only $20 \%$ of respondents are satisfied on the support received after the disaster, while $80 \%$ of respondents are not satisfied with that support. The support in the field of disasters is almost non-existent i.e. EPVH is unable despite its plea to the provincial and/or national authorities and different partners, to come in support of the victims of environmental disasters.

Depending on the nature of disasters occurring in this area, $54 \%$ of disasters originate from the bushfire while $46 \%$ originate from the flood. The bushfire is much more evident in the Bodangabo sector and that of Karawa while the flooding is perceived in the Businga sector as the $3 / 4$ of this sector is largely surrounded by rivers namely Likpolo, Lokame, Legbala and Mongala. 
Table 1. Socio-demographic characteristics of respondents

\begin{tabular}{lll}
\hline Variables & Frequency $\mathbf{( n = 1 5 0 )}$ & Percentage (\%) \\
\hline Sex & & 65 \\
\hline Male & 98 & 35 \\
Female & 52 & 17 \\
\hline Age (years) & 26 & 8 \\
\hline $23-27$ & 12 & 7 \\
$28-32$ & 11 & 4 \\
$33-37$ & 6 & 20 \\
$38-42$ & 29 & 9 \\
$43-47$ & 14 & 8 \\
$48-52$ & 12 & 16 \\
$53-57$ & 24 & 11 \\
$58-62$ & 16 & 80 \\
63 and above & & 20 \\
\hline Marital status & 120 & \\
\hline Married & 30 & 8 \\
Single & & 20 \\
\hline Level of education & 12 & 56 \\
\hline Illiterate & 30 & 16 \\
Primary & 84 & \\
Secondary & 24 & 84 \\
University & & 10 \\
\hline Duties & 126 & 6 \\
\hline Victims of disaster & 15 & 20 \\
Solidarity and humanitarian & 10 & 52 \\
Red Cross & & 16 \\
\hline Seniority in the area & 30 & 12 \\
\hline Less than 5 years & 78 & \\
Between 5 and 10 years & 24 & \\
Between 10 and 20 years & 18 & \\
More than 20 years & & \\
\hline
\end{tabular}

Bodangabo sector

Businga sector

Karawa sector

Businga city

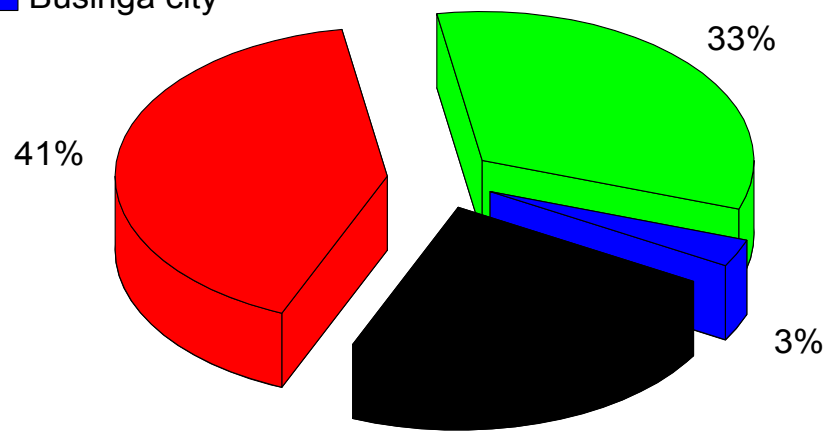

$23 \%$

Fig. 1. Areas vulnerable to environmental disasters 
Table 2. Level of knowledge on the prevention and management of environmental disasters in Businga territory

\begin{tabular}{lcc}
\hline Variables & Frequency $(\mathbf{n}=\mathbf{1 5 0})$ & Percentage $\mathbf{( \% )}$ \\
\hline Knowledge on prevention and management of environmental disasters & \\
\hline Yes & 138 & 92 \\
No & 12 & 8 \\
\hline Origin of environmental disasters & & \\
\hline Flooding & 81 & 54 \\
Bushfire & 69 & 46 \\
\hline Level of satisfaction on the environmental disaster support system & 80 \\
\hline Satisfied & 120 & 20 \\
Not satisfied & 30 & \\
\hline Types of support for victims & & 60 \\
\hline Food supplies & 90 & 40 \\
Primary healthcare & 60 & \\
\hline
\end{tabular}

It is clearly observed that $60 \%$ of respondents received food supplies as support while $40 \%$ received the primary healthcare support. Mwape [18], reported the damages of flooding on crops and different infrastructures. If crops are destroyed, this will bring hunger and drought, hence the need of food supplies so that the victims may survive. However, flooding plays an important role in the outbreak and the spread of infectious diseases as it creates conditions for the multiplication of pathogens and vectors [14]. One of the most effective health interventions to avoid the outbreak of infectious diseases resulting from flooding is to develop Early Warning Systems for infectious diseases by considering flooding trends. It allows those at risk to either evacuate or take precautionary measures and the public health sector to sufficiently prepare for the eventualities [14]. On the other side, the emergency response planning constitutes also another health intervention. This should entail well planned emergency procedures for health systems designed and established well in advance of the flooding hazard in order to provide a basis for effective health care during and after flooding [41].

The occurrence period of environmental disasters in Businga territory is given in the Fig. 2.

The occurrence period of environmental disasters is mainly in the dry season precisely the bushfire which occurs between December and February, while the flooding as a disaster occurs in the rainy season. This phenomenon is mostly observed between September and October. Mwape [18] reported that the most common causes of floods are climate related, most notably rainfall. Prolonged rainfall events are the most common cause of flooding worldwide. These events are usually associated with several days, weeks or months of continuous rainfall.

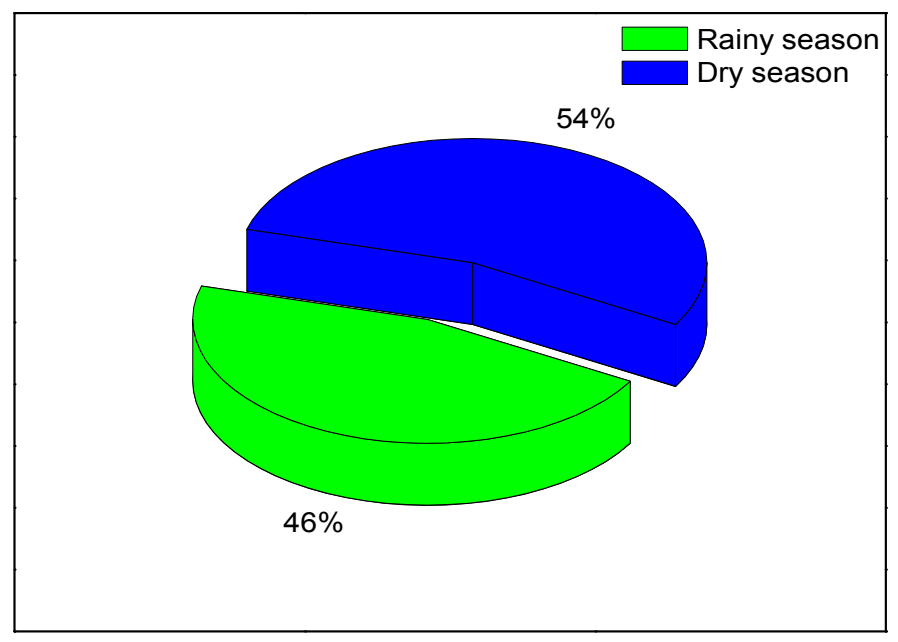

Fig. 2. Occurrence period of environmental disasters in Businga territory 


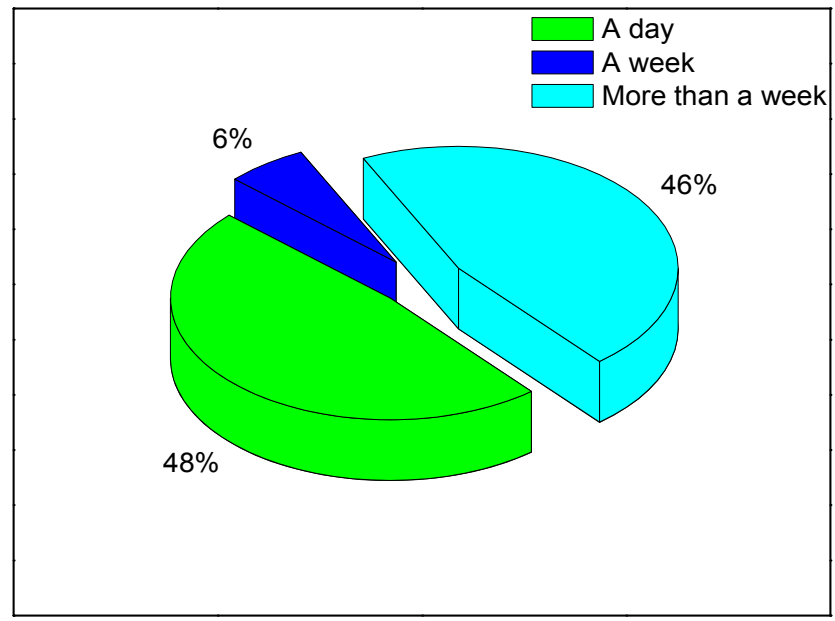

Fig. 3. Duration of disasters

The duration of the disaster occurrence is described in the Fig. 3.

The duration of disasters varies from one day to one week for bushfire and more than a week for flooding. Since the existing support system is inoperative, the more the catastrophe, the more the population is exposed to the vagaries. Being in this situation, the population of Businga are exposed to different pathologies which have bad consequences on their health. Okaka et al. [14] reported that flooding has a wide range of health consequences such as drowning, injury, outbreak of gastroenteritis, respiratory infections, poisoning, communicable diseases, epidemic diseases such as cholera, diarrhea, and dengue fever, poor mental health, and disability. On the other side, public health interventions are really needed in order to reduce the vulnerability to infections as a result of flooding i.e. interventions range from those made before, during and after flooding. Bushfires are accompanied by a range of acute health impacts, and an increase in number of patients seeking for emergency services [42]. These adverse impacts include: respiratory conditions, cardiac problems, heat stress, trauma, mental health even death. The health impacts of bushfires can be severe and long lasting, but can be reduced through bushfire prevention, preparation and education. All these health disturbances are due to toxic compounds released by bushfires smoke like carbon monoxide [42]. After the bushfire occurrence, the cleaning up can expose workers to hazardous materials including asbestos, lead, copper, chromium and arsenic, or ash containing those substances [42].

Fig. 4 shows the different velocities of disaster occurrence.

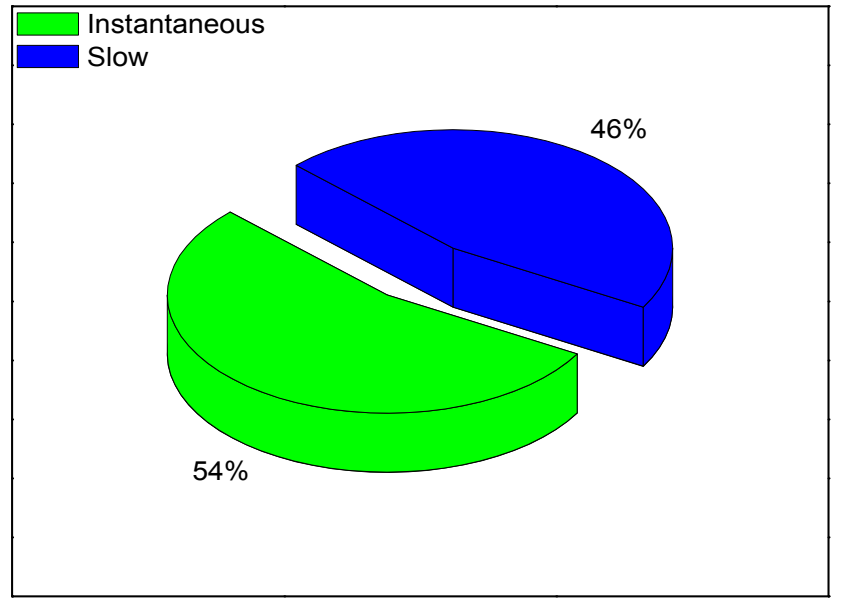

Fig. 4. Speed of emergence of environmental disasters 
The speed of disaster occurrence is instantaneous in terms of bushfire and slow for flooding while it is very difficult to manage when this starts. This is due to the poor use of fire in the bush during the dry season and to a gradual increase in water level.

\subsection{Attitude of Respondents on Disaster Prevention and Management System, Existence of Policy at Provincial and Community Levels and the Role of Humanitarian Watch Team}

The attitude of respondents on different aspects on disaster prevention and management system is presented in Table 3.

The mode of disaster prevention in Businga territory is ineffective, as NGOs responsible for disaster prevention and management are not equipped for disasters. The minority proposed the system for the prevention of environmental disasters to be used in Businga territory. Therefore, $61 \%$ proposed the sanitation and environmental management in order to avoid bushfire while $39 \%$ suggested that the population should avoid the anarchic building in swampy environments to avoid flooding.

Regarding the existence of policy at the provincial level, $96 \%$ of respondents denied the contribution of the provincial government while $4 \%$ of respondents confirmed the provincial government contribution to these disasters i.e. the existence of a policy that the government has set in order to manage disasters. However, the contribution is often from NGOs via national and international partners. Concerning the existence of policy on prevention and management of disasters at the community level, $92 \%$ of respondents reported the complete absence of the policy on prevention and management of environmental disasters at the community level.

Table 3. Attitude of respondents on different aspects of disaster prevention system, existence of policy at the provincial and community levels and the role of humanitarian monitoring team

\begin{tabular}{|c|c|c|}
\hline Variables & Frequency $(n=150)$ & Percentage (\%) \\
\hline \multicolumn{3}{|l|}{ Possibility of prevention } \\
\hline Yes & 18 & 12 \\
\hline No & 132 & 88 \\
\hline \multicolumn{3}{|l|}{ Mode of prevention } \\
\hline Sanitation of the area & 93 & 61 \\
\hline Avoid the anarchic constructions & 57 & 39 \\
\hline \multicolumn{3}{|c|}{$\begin{array}{l}\text { Existence of policy on prevention and management of environmental disasters at provincial } \\
\text { level }\end{array}$} \\
\hline Existent & 144 & 96 \\
\hline Non-existent & 6 & 4 \\
\hline \multicolumn{3}{|c|}{$\begin{array}{l}\text { Existence of policy on prevention and management of environmental disasters at community } \\
\text { level }\end{array}$} \\
\hline Existent & 138 & 92 \\
\hline Non-existent & 12 & 8 \\
\hline \multicolumn{3}{|c|}{ Existence of disaster warning system } \\
\hline Existent & 25 & 17 \\
\hline Non-existent & 125 & 83 \\
\hline \multicolumn{3}{|c|}{ Possibility of existence of the provincial humanitarian monitoring team } \\
\hline Existent & 108 & 72 \\
\hline Non-existent & 42 & 28 \\
\hline \multicolumn{3}{|c|}{ Role of humanitarian monitoring team } \\
\hline Existent & 102 & 68 \\
\hline Non-existent & 48 & 32 \\
\hline \multicolumn{3}{|c|}{ Past disasters and their periods of occurrence } \\
\hline Flooding 2012, 2014, 2016 & 69 & 46 \\
\hline Bushfire & 81 & 54 \\
\hline \multicolumn{3}{|c|}{ Difficulties on prevention and management of disasters } \\
\hline Lack of awareness & 102 & 68 \\
\hline Lack of qualified personnel & 48 & 32 \\
\hline
\end{tabular}



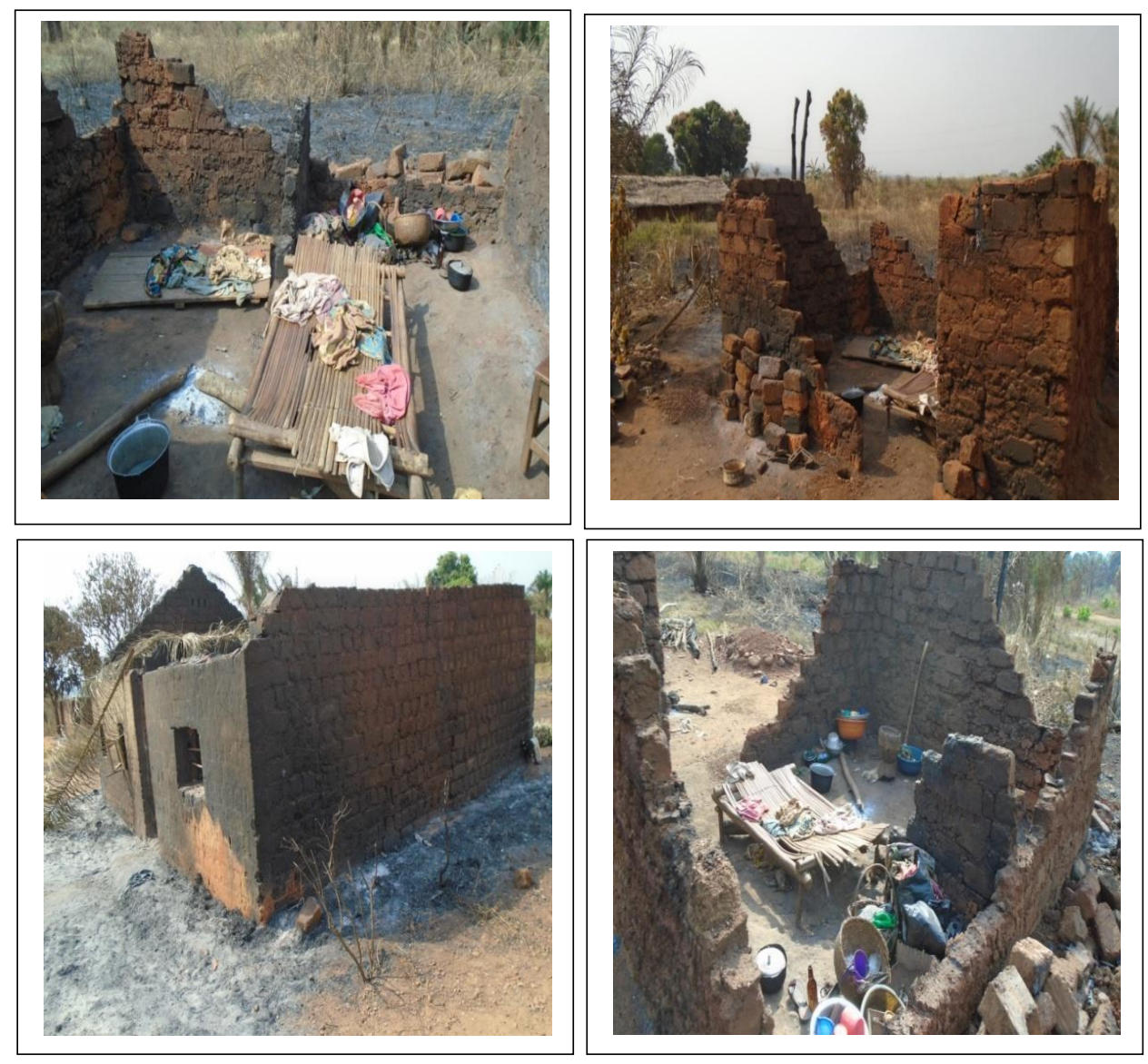

Fig. 5. Some illustrations of the disasters happening to the Businga territory (Source: Nzamonga, 2017)

Concerning the early warning system, this device was supposed to be installed throughout the territory under EPVH direction in order to transmit good information on environmental disasters is not found in all sectors of Businga. That's why, at the occurrence of a disaster there is no concordance on the outcome reported, because stakeholders report information collected from their structure located in Businga. The need of early warning system is requested in Gbadolité though DRC always possesses an early warning system for disaster management with the help of Catholic Relief Services and UNICEF, and it was implemented in two provinces namely Katanga and Kasai. Unfortunately, this system was not efficient [43].

However, the set of capacities needed to generate and disseminate timely and meaningful warning information to enable individuals, communities and organizations threatened by a hazard to prepare and to act appropriately and in sufficient time to reduce the possibility of harm or loss [44]. This definition encompasses the range of factors necessary to achieve effective responses to warnings. A people-centred early warning system necessarily comprises four key elements: Knowledge of the risks; monitoring, analysis and forecasting of the hazards; communication or dissemination of alerts and warnings; and local capabilities to respond to the warnings received. The expression "end-to-end warning system" is also used to emphasize that warning systems need to span all steps from hazard detection through to community response [44].

With regards to the role of humanitarian monitoring team, $62 \%$ of respondents confirmed that the EPVH team does not exercise its role of bringing together stakeholders involved, raising awareness and advocating to the stakeholders. This situation is due to the lack of funding. Reason why there is slowness in the prevention 
and management of environmental disasters in Businga territory. However, it is important to draw on the experience of other countries. To this end, the system of prevention and management of environmental disasters in Cameroon with regard to international environmental law shows that this country had set up a strategy dealing with degradation by reducing these disasters through prevention and reduction of threats [10]. This system can be applied in the territory of Businga in order to reduce the threats and frequency of occurrence of these disasters (Fig. 5). The three levers alluded by Provitolio et al. [45]: development policies, civil engineering and population training so that they can best adapt their behavior to disaster situations, are a solution to the problems of environmental disasters in the territory of Businga.

Schelf, [15] gave some recommendations which help to find solutions to flooding, many of which overlap the mitigation measures. These recommendation are the following: (i) a flood early warning system, (ii) improved storm water management and delimitation of zones at-risk of flooding, (iii) enforcement of zoning laws, (iv) building houses with concrete, and ( $v$ ) risk management plans. These recommendations are also valuable for the case of DRC where the government needs to install an early warning system against environmental disasters. Furthermore, participants indicated the need for education about flood risks and one public official mentioned the need for direct involvement of the population in flood risk management. The primary solutions recommended can be summarized as better finances for risk reduction, investment in the necessary human resources, and development and implementation of an early warning system [15].

From the past disaster occurrence, it is clearly shown that floods are sporadic i.e. almost every two compared to the bushfire which is manifested each year in Businga territory, Nord Ubangi province, DRC. The latest floods which occurred in Businga was at the space of two years. This observation helped to state flooding occurred each two years in this neighborhood.

Concerning difficulties on the prevention and management of environmental disasters, $68 \%$ of respondents reported difficulties are due to the lack of awareness because of the lack of financial means compared to $32 \%$ of respondents who reported the shortage of qualified personnel in the prevention and management of these disasters. Several factors have inhibited the response to disasters include, lack of a nationallevel plan policy, absence of an institutional framework at the center / state / district level, poor inter-sectoral coordination, lack of an early warning system, slow response from the relief agencies, lack of trained / dedicated search and rescue teams, and poor community empowerment [5]. For instance, Indian government has integrated administrative machinery for the management of disasters at the National, State, District, and Sub-District levels. The basic responsibility of undertaking rescue, relief, and rehabilitation measures in the event of natural disasters, as at present, is that of the concerned State Governments. The Central Government supplements the efforts of the State by providing financial and logistic support. Besides this, the Indian Armed Forces are called upon to intervene and take on specific tasks if the situation is beyond the capability of civil administration [5]. The Congolese government has to follow the above example of the Indian government for instance so that he can improve its management at all levels.

\section{CONCLUSION AND SUGGESTIONS}

The aim of the current study was to assess the knowledge, perceptions and attitudes of victims and stakeholders on environmental disasters in Businga territory. The findings showed that the most common environmental disasters occurring in Businga territory are flooding and bushfires.

The flooding period occurrence is every two years precisely during the raining season. While the bushfire period occurrence is of a year mainly during the dry season. This situation is due to the irresponsibility of the community along with the stakeholders of Businga sectors. The lack of prevention and management of environmental disaster policy both at the provincial and community level is at the base of this high frequency occurrence. Henceforth, the necessity of installing the early warning system for a better prevention.

Moreover, there is an emergency of settling a provincial body which responsibility would be to alert and advocate with the stakeholders involved in the prevention and management of environmental disasters in Businga territory seeing the inefficiency of the humanitarian monitoring team. This body would help in monitoring the humanitarian team and giving clear and reliable information on disaster 
occurrence in this area, which would sensitize the community so that they can mitigate disaster frequency. Anyway, sanitation measures and the implementation of the humanitarian monitoring team will be needed to mitigate environmental disasters in this part of the Nord-Ubangi together with the local community.

\section{COMPETING INTERESTS}

Authors have declared that no competing interests exist.

\section{REFERENCES}

1. Mulumba M, Kabanda D, Nassuna V. Constitutional provisions for the right to health in east and southern Africa; EQUINET Discussion Paper 81. Centre for Health, Human Rights and Development, Regional Network for Equity in Health in East and Southern Africa (EQUINET): Harare, Zimbabwe. 2010;27.

2. President's office. Constitution of the Democratic Republic of the Congo. Official Journal of the DRC. 2011;89.

3. The International Bank for Reconstruction and Development / The World Bank. Natural hazards, unnatural disasters: The Economics of Effective Prevention. Washington, USA. 2010;208.

4. Pradhan A. Disasters and disaster management: Some reflections. Scholarly Research Journal for Humanity Science and English Language. 2016;3(15):37213730.

5. Srivastava K. Disaster: Challenges and perspectives. Industrial Psychiatry Journal. 2010;19(1):1-4.

6. Mohanty R. Impact of disaster on disabled women special reference TO Jagatsinghpur district. Shanta Memorial Rehabilitation Centre Bhubaneswar, School of Women's studies, Utkal University. 2005;135.

7. National Institute of Disaster Management. Understanding disasters. Ministry of Home Affairs, Government of India. 2019;7.

Available:http://nidm.gov.in/PDF/Disaster_a bout.pdf

(Accessed on January 10, 2019 at 16:00)

8. Barasa B. Increased incidences, intensity and scope of disasters: Manifestation of unsustainable development practices. Environment Pollution and Climate Change. 2018;2(2):1-9.
9. Davis JR, Sacoby W, Brock-Martin A, Glover S, Svendsen ER. The impact of disasters on populations with health and health care disparities. Disaster Medicine and Public Health Preparedness. 2010; 4(1):30-38.

10. Tahitie BTN. The system of prevention and management of environmental disasters in Cameroon and international environmental law. Master's thesis in International and Comparative Law of the Environment, Faculty of Law and Economics of Limoges, University of Limoges, France. 2010;65.

11. Muhigirwa $\mathrm{G}$. The approach of prevention and management of natural risks in Burundi and the international law of the environment. Bachelor's Thesis, United Nations Institute for Training and Research. 2011;87.

12. Mata-Lima $\mathrm{H}$, Alvino-Borba $\mathrm{A}$, Pinheiro $\mathrm{A}$, Mata-Lima A, Almeida JA. Impacts of natural disasters on environmental and socio-economic systems: What makes the difference? Ambiente \& Sociedade. 2013; 16(3):45-64.

Available:http://dx.doi.org/10.1590/S1414753X2013000300004

13. Adeleke OO, Jimoh YA, Ayanshola AM, Aremu AS. Role of geomatics in the management of disasters and infrastructural failures. Ethiopian Journal of Environmental Studies and Management. 2013;6(2):143-148.

14. Okaka FO, Odhiambo BDO. Relationship between flooding and outbreak of infectious diseases in Kenya: A Review of the literature. Journal of Environnemental and Public Health. 2018;5452938:8.

15. Schlef K. Flood risk assessment, management and perceptions in a changing world. Unpublished doctoral dissertation, Department of Civil and Environmental Engineering, University of Massachusetts AMHERST, USA. 2018;194.

16. Benson C, Clay E. Economic and financial impacts of natural disasters: An Assessment of their effects and options for mitigation: Synthesis report. Overseas Development Institute, London, United Kingdom. 2003;128.

17. European Environment Agency (EEA). Mapping the impacts of natural hazards and technological accidents in Europe: An overview of the last decade. Technical Report, Copenhagen. 2010;146. 
18. Mwape YP. An impact of floods on the socio-economic livelihoods of people: A case study of Sikaunzwe Community in Kazungula District of Zambia. Unpublished MSc Dissertation, Disaster Risk Management Training and Education Centre for Africa (DiMTEC), Faculty of Natural and Agricultural Sciences, University of the Free State, Zambia. 2009;87.

19. Verschuur J. Flood risk evaluation: Validation and smart flood risk city management. Unpublished BSc Dissertation, Civil Engineering Department, Delft University of Technology. 2016;67.

20. Thieken $\mathrm{AH}$, Kienzler $\mathrm{S}$, Kreibich $\mathrm{H}$, Kuhlicke C, Kunz M, Mühr B, Müller M, Otto A, Petrow T, Pisi S, Schröter K. Review of the flood risk management system in Germany after the major flood in 2013. Ecology and Society. 2016;21(2):51. Available:http://dx. doi.org/10.5751/ES08547-210251

21. Dick L. Fire, flood and Ice: Search and rescue missions of the South African Air Force. Covos Books, Johannesburg. 1998;215.

22. Du Plessis LA. A review of effective flood forecasting, warning and response system for application in South Africa. Water SA. 2002;28(2):129-138.

23. Dube E, Mtapuri O, Matunhu J. Managing flood disasters on the built environment in the rural communities of Zimbabwe: Lessons learnt. Jàmbá: Journal of Disaster Risk Studies. 2018;10(1):a542.

Available:https:// doi.org/10.4102/jamba. v10i1.542

24. United States Agency for International Development (USAID). Southeast Asia Floods. Fact Sheet, Fiscal Year. 2012;1-6.

25. Olorunfemi FB, Adebimpe RU. Sustainable disaster risk reduction in Nigeria: Lessons for Developing countries. African Research Review. 2002;2(2):187-217.

26. Ismail MD, Mustaquim. Socio-economic status of population in flood prone areas of Chanchal sub-division in Malda district, West Bengal. International Journal of Research in Applied, Natural and Social Sciences. 2012;1(3):141-152.

27. Theron M. Climate change and increasing floods in Africa: Implication for Africa's development; 2007.

28. Kummu $M$, de Moel $H$, Ward $P$, Varis $O$. How close do we live to water? A global analysis of population distance to freshwater bodies. PloS One. 2011;6(6):113,e20578.

Available:https://doi.org/10.1371/journal.po ne.0020578

29. Disaster Relief Emergency Fund (DREF). Democratic Republic of the Congo: Floods in Gemena. International Federation of Red Cross and Red Crescent Societies. 2017;8.

30. Disaster Relief Emergency Fund (DREF). Democratic Republic of the Congo: Floods in Kinshasa. International Federation of Red Cross and Red Crescent Societies. 2008;4.

31. Disaster Relief Emergency Fund (DREF). Emergency Plan of Action (EPOA): Democratic Republic of the Congo: Floods in Kinshasa. International Federation of Red Crescent Societies. 2018;16.

32. Provincial Humanitarian Monitoring Team (EPVH). Annual report; 2018.

33. Morris JT. Emergency field operations pocketbook. United Nations World Food Programme (WFP). 2002;180.

34. Public Transport Authority. Bushfire management strategy. Public Transport Centre, West Parade, Australia. 2017;10.

35. Price J, Mraz J, Grant N. Bushfires: A geography resource for Australian students. First edition published by the Country Fire Authority and Geography Teachers' Association of Victoria Inc, Australia. 2012;57.

36. Lewis JA, Yeboah IAA. Movement under environmental disasters: The case of flooding and bushfires for selected periods in Ghana. 2011;20.

37. Ngbolua $\mathrm{KN}$, Mafoto A, Molongo $\mathrm{M}$, Magbukudua JP, Ngemale GM, Masengo CA, Patrick K, Yabuda H, Zama J, Veke F. Evidence of new geographic localization of Okapia johnstoni (Giraffidae) in Democratic Republic of the Congo: The rainforest of "Nord Ubangi" district. Journal of Advanced Botany \& Zoology. 2014;2(1).

DOI: 10.15297/JABZ.V2I1.02, 2014

38. Ngbolua $\mathrm{KN}$, Mafoto $\mathrm{A}$, Molongo $\mathrm{M}$, Ngemale GM, Masengo CA, Gbolo ZB, Mpiana PT, Bongo GN. Contribution to the inventory of "Protected Animals" Sold as bush meats in some markets of Nord Ubangi province, Democratic Republic of the Congo. Journal of Advancement in Botany and Zoology. 2015;3(2).

DOI: 10.15297/JABZ.V3I2.02

39. Jongman B, Hochrainer-Stigler S, Feyen L, Aerts J, Mechler R, Botzen W, Bouwer L, Pflug G, Rojas R, Ward P. Increasing 
stress on disaster-risk finance due to large floods. Nature Climate Change. 2014;4: 264-268.

DOI: $10.1038 /$ nclimate2124

40. Ngunyi WE. Community organizing in achieving resilience to disasters: The case of fire disasters in Gikomba market. Unpublished MA in Disaster Management dissertation, Department of Sociology and Social Work, University of Nairobi, Nairobi, Kenya. 2011;106.

41. Few R, Ahern M, Matthies F, Kovats RS. Floods, health and climate change: $A$ strategic review. Tyndall Centre for Climate Change Research Working Paper 63, University of East Anglia, Norwich, UK. 2004;138.

42. Doctors for the Environment Australia (DEA). Bushfires and health in a changing environment. Fact sheet Healthy planet, healthy people. 2017;4.
43. Moumane D, Huynh L, Kashoshi M, Kabiona S. Early warning systems in central DR of Congo: Saving lives through faster emergency response. Catholic Relief Services, Baltimore, USA. 2012;32.

44. United Nations International Strategy for Disaster Reduction (UNISDR). Disaster risk reduction. United Nations, Geneva, Switzerland. 2009;35.

45. Provitolo $D$, Dubos-Paillard $E$, Verdière $N$, Lanza V, Charrier R, Bertelle C, AzizAlaoui MA. Human behavior in disaster situations: From observation to conceptual and mathematical modeling. Cybergeo: European Journal of Geography [Online], Systems, Modelling, Geostatistics, document 735, Online since 10 September 2015, connection on 25 January 2019. Available:http://journals.openedition.org/cy bergeo/27150 DOI: $10.4000 /$ cybergeo.27150

(0) 2019 Ngbolua et al.; This is an Open Access article distributed under the terms of the Creative Commons Attribution License (http://creativecommons.org/licenses/by/4.0), which permits unrestricted use, distribution, and reproduction in any medium, provided the original work is properly cited.

Peer-review history:

The peer review history for this paper can be accessed here: http://www.sdiarticle3.com/review-history/45800 